\title{
DAMPAK PENERAPAN PUNGUTAN EKSPOR CRUDE PALM OIL TERHADAP KINERJA AGRIBISNIS KELAPA SAWIT DAN PENDAPATAN PETANI INDONESIA
}

\author{
Maswadi \\ Dosen Jurusan Agribisnis Fakultas Pertanian \\ Universitas Tanjungpura Pontianak \\ Abstract
}

Crude Palm Oil (CPO) is a strategic commodity in the economy of Indonesia. CPO industry also plays an important role in the international market. The rate of growth of production of CPO is the highest among the categories of oil consumed. Even a CPO has predicted will pass trade oil for soybeans at most in the world market be trading.

The current Government had new instruments in international trade activities, i.e. the export levy of dilegalisasi on September 10, 2005 with the publication of legislation No. 33 of 2005. Broadly speaking stakeholders agribusiness palm national associate substance of the purpose and size of the export levy rate as well as benchmark price export with benefit dimension, justice and legal certainty. After looking closely at legislation of the export levy in the perspective of the development of oil palm industry, there are 2 national article that needs to be understood in depth. The second chapter is chapter 2, about the purpose and article 3 paragraph 5 and 6 , of the size of export the levy rate and export benchmark prices. Both articles still contain questions like: "whether its value has been considering concrete benefits for all palm oil stakeholders national, meet the sense of justice and legal certainty in their implementation?".

The review of this paper aims to discuss about the purpose of the application of the export levy and export benchmark prices taking into account its benefits for all stakeholders to the national burden of palm oil, which must be borne by the stakeholders and legal certainty, and their impact on the performance of the agribusiness palm and farmer income in Indonesia.

Keywords : Crude Palm Oil, Export Levy, Indonesia 


\section{PENDAHULUAN}

Sistem agribisnis tidak sama dengan sektor pertanian. Sistem agribisnis jauh lebih luas daripada sektor pertanian yang dikenal selama ini. Sistem agribisnis terdiri dari tiga subsistem utama, yaitu: Pertama, subsistem agribisnis hulu (upstream agribusiness) yang merupakan kegiatan ekonomi yang menyediakan sarana produksi bagi pertanian, seperti industri dan perdagangan agrokimia (pupuk, pestisida, dll), industri agrootomotif (mesin dan peralatan), dan industri benih/bibit. Kedua, subsistem usahatani (onfarm agribusiness) yang merupakan kegiatan ekonomi yang menggunakan sarana produksi yang dihasilkan oleh subsistem agribisnis hulu untuk menghasilkan produk pertanian primer. Termasuk ke dalam subsistem usahatani ini adalah usaha tanaman pangan, usaha tanaman hortikultura, usaha tanaman obat-obatan, usaha perkebunan, usaha perikanan, usaha peternakan, dan kehutanan. Ketiga, subsistem agibisnis hilir (down-stream agribusiness) yang berupa kegiatan ekonomi yang mengolah produk pertanian primer menjadi produk olahan, baik produk antara maupun produk akhir, beserta kegiatan perdagangan di pasar domestik maupun di pasar internasional. Kegiatan ekonomi yang termasuk dalam subsistem agibisnis hilir ini antara lain adalah industri pengolahan makanan, industri pengolahan minuman, industri pengolahan serat (kayu, kulit, karet, sutera, jerami), industri jasa boga, industri farmasi dan bahan kecantikan, dan lain-lain beserta kegiatan perdagangannya.

Disamping ketiga subsistem di atas, diperlukan subsistem keempat sebagai bagian dari pembangunan sistem agribisnis. Subsistem keempatini dikenal sebagai subsistem penunjang. Subsistem penunjang adalah seluruh kegiatan yang menyediakan jasa bagi agribisnis, seperti lembaga keuangan, lembaga penelitian dan pengembangan, lembaga transportasi, lembaga pendidikan, dan lembaga pemerintah (kebijakan fiskal dan moneter, perdagangan internasional, kebijakan tata-ruang, serta kebijakan lainnya).

Peranan agribisnis dalam perekonomian Indonesia sangat penting. Memang belum ada data kuantitatif yang secara eksplisit dapat menggambarkan peranan agribisnis ini. Agribisnis tidak digambarkan sebagai suatu sektor yang secara jelas tercatat kontribusinya dalam pembentukan PDB ataupun penyerapan tenaga kerja. Sehingga diperlukan penghitungan ulang terhadap datadata yang ada yang disesuaikan dengan definisi agribisnis.

Pembangunan agribisnis di masa yang lalu banyak mengalami hambatan kebijakan. Salah satu kebijakan yang sangat merugikan agribisnis adalah kebijakan yang mengakibatkan nilai rupiah menjadi terlalu tinggi (overvalued 
exchangerate). Nilai rupiah yang terlalu tinggi identik dengan memberikan 'subsidi' nilai tukar bagi kegiatan impor dan sekaligus Maswadi, Dampak Penerapan bagi kegiatan impor dan sekaligus
Pungutan Ekspor Crude Palm membebani 'pajak' nilai tukar bagi
Oil... aktivitas ekspor. Impor bahan baku dan bahan penolong yang diperlukan industri (substitusi impor ataupun footloose) menjadi relatif lebih murah dalam rupiah. Sebaliknya produk ekspor Indonesia menjadi relatif mahal dalam mata uang asing. Dapat diperkirakan keadaan ini menyebabkan impor meningkat dan ekspor terhambat, sehingga terjadi defisit transaksi berjalan. Nilai tukar rupiah yang over valued ini merugikan agribisnis nasional, terutama subsistem usahatani. Nilai tukar yang over valued ini menghambat ekspor komoditas pertanian, sehingga beberapa komoditas yang pernah menjadi andalan ekspor Indonesia seperti gula, jagung, dan daging sapi berubah menjadi komoditas impor.

Dalam perekonomian suatu negara, kebijakan perdagangan internasional berperan sangat penting. Kebijakan perdagangan tersebut pada umumnya diutamakan untuk perluasan pasar internasional dan proteksi bagi pembeli domestik (industri atau rumah tangga). Namun tidak tertutup kemungkinan, kebijakan perdagangan tersebut ditujukan untuk meningkatkan penerimaan pemerintah melalui pajak/pungutan dan terkait dengan kebijakan luar negeri suatu negara atau alasan-alasan politik. Dalam konteks ini, kebijakan pemerintah tentang penerapan PE untuk CPO dan produk turunannya lebih diutamakan untuk meningkatkan penerimaan pemerintah dan proteksi bagi industri dalam negeri penghasil produk turunan $\mathrm{CPO}$, seperti industri minyak goreng dan oleokimia.

Crude Palm Oil (CPO) merupakan salah satu komoditas strategis dalam perekonomian Indonesia. Pertama, sebagai bahan utama minyak goreng yang dikonsumsi masyarakat, CPO memainkan peran penting dalam menentukan tingkat inflasi. Kedua, industri palm oil menyerap lebih dari dua juta orang tenaga kerja. Ketiga, ekspor CPO merupakan sumber devisa negara yang telah menghasilkan lebih dari satu juta USD sejak tahun 1997 hingga kini. Industri CPO juga memainkan peran penting di pasar internasional. Laju pertumbuhan produksi CPO merupakan yang tertinggi diantara kategori minyak lainnya yang dikonsumsi. Bahkan CPO telah diprediksi akan melewati perdagangan minyak kedelai yang selama paling banyak diperdagangkan di pasar dunia.

Dengan strategisnya posisi CPO dalam perekonomian, pemerintah telah merilis kebijakan untuk mengoptimalkan pembangunan industrinya. Salah satu kebijakan penting tersebut adalah kebijakan pajak ekspor yang pertama dimplementasikan pada bulan Agustus 1994 untuk menstabilkan dan mengamankan pasokan dan harga. Pajak ekspor yang pada awalnya dikenakan pada CPO berkisar antara $40-60 \%$ 
yang dihitung secara berbeda berdasarkan harga CPO internasional dan harga patokan ekspor. Sejak 4 Juli 1987 sampai Februari 1998, pajak ekspor turun menjadi 5\% dari harga CPO. Kemudian, selama masa krisis ekonomi yang menyebabkan harga CPO meningkat tajam dan depresiasi Rupiah, pemerintah melarang ekspor CPO diawal tahun 1998. Kondisi ini menyebabkan perubahan kabijakan pajak ekspor yang sangat drastis, yaitu peningkatan pajak ekspor dari 5\% menjadi $60 \%$ yang kemudian turun lagi menjadi $30 \%$ pada Juli 1999 dan 4\% pada tahun 2002.

Saat ini pemerintah mempunyai instrumen baru dalam kegiatan perdagangan internasional, yaitu pungutan ekspor (PE) yang dilegalisasi pada tanggal 10 September 2005 dengan penerbitan PP No. 35 Tahun 2005. PP ini pada dasarnya sebagai pengganti SK Menteri Keuangan tentang pajak ekspor yang untuk kelapa sawit telah diterapkan sejak tahun 1984. Selain itu, PP ini dimaksudkan untuk melaksanakan amanat peraturan perundangundangan yang telah berlaku secara nasional diantaranya UU No. 20 Tahun 1997 tentang
Penerimaan Negara Bukan Pajak (PNBP).

\section{KONDISI AGRIBISNIS} KELAPA SAWIT INDONESIA

Melalui berbagai upaya pengembangan, baik yang dilakukan oleh perkebunan besar, proyek-proyek pembangunan maupun swadaya masyarakat,perkebunan kelapa sawit telah berkembang sangat pesat. Pada tahun 2000, luasareal yang seluas 4.158.079 ha menjadi 8.248.328 ha pada tahun 2009 . Selain daripertumbuhan areal yang cukup besar tersebut, hal lain yang lebih mendasar lagiadalah penyebarannya, yang semula hanya ada pada 3 propinsi saja di Sumatera,tetapi saat ini telah tersebar di 21 propinsi di Indonesia. Sumatera masih memilikiareal terluas di Indonesia, yaitu mencapai $75,98 \%$, diikuti Kalimantan danSulawesi, masingmasing 20,53\% dan $2,81 \%$. Produksi kelapa sawit juga telah menyebar ke berbagai wilayah Indonesia dengan perbandingan $85,55 \% \quad$ Sumatera, $11,45 \%$ Kalimantan, 2\%, Sulawesi, dan 1\% wilayah lainnya.

Data luas areal, produksi dan produktivitas kelapa sawit Indonesia selengkapnya disajikan pada Tabel 1 dan Tabel 2 berikut: 


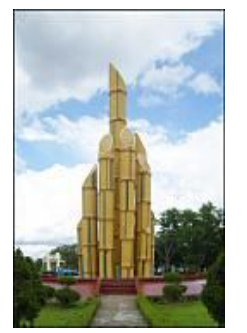

Tabel 1. Data Luas Areal, Produksi dan Produktivitas Kelapa Sawit Indonesia (Nasional)

Maswadi, Dampak Penerapa Pungutan Ekspor Crude Palm Oil....

\begin{tabular}{|c|c|c|c|}
\hline Tahun & $\begin{array}{c}\text { Luas Areal } \\
(\mathbf{H a})\end{array}$ & $\begin{array}{c}\text { Produksi } \\
\text { (Ton) }\end{array}$ & $\begin{array}{c}\text { Produktivitas } \\
(\mathbf{K g} / \mathbf{H a})\end{array}$ \\
\hline 2000 & 4.158 .079 & 4.158 .079 & 4.158 .079 \\
\hline 2001 & 4.713 .435 & 4.713 .435 & 4.713 .435 \\
\hline 2002 & 5.067 .058 & 5.067 .058 & 5.067 .058 \\
\hline 2003 & 5.283 .557 & 5.283 .557 & 5.283 .557 \\
\hline 2004 & 5.284 .723 & 5.284 .723 & 5.284 .723 \\
\hline 2005 & 5.453 .817 & 5.453 .817 & 5.453 .817 \\
\hline 2006 & 6.594 .914 & 6.594 .914 & 6.594 .914 \\
\hline 2007 & 6.766 .836 & 6.766 .836 & 6.766 .836 \\
\hline 2008 & 7.363 .847 & 7.363 .847 & 7.363 .847 \\
\hline 2009 & 8.248 .328 & 8.248 .328 & 8.248 .328 \\
\hline
\end{tabular}

Sumber : Data Departemen Pertanian, 2010

Komposisi pengusahaan kelapa sawit juga mengalami perubahan, yaitu dari sebelumnya hanya perkebunan besar, tetapi saat ini telah mencakup perkebunan rakyat dan perkebunan swasta. Pada tahun 2009, luas areal perkebunan rakyat mencapai $3,013,973$ ha $(40,1 \%)$, perkebunan negara seluas 608,580 ha $(8,1 \%)$ dan perkebunan besar swasta seluas $3,885,470$ ha $(51,8 \%)$. Sumatera mendominasi ketiga jenis pengusahaan, sedangkan Kalimantan dan Sulawesi menjadi lokasi pengembangan perkebunan swasta dan perkebunan rakyat

LUAS AREAL DAN PRODUKSI PERKEBUNAN SELURUH INDONESIA Komoditi:Kelapa Sawit (Ton) 2009

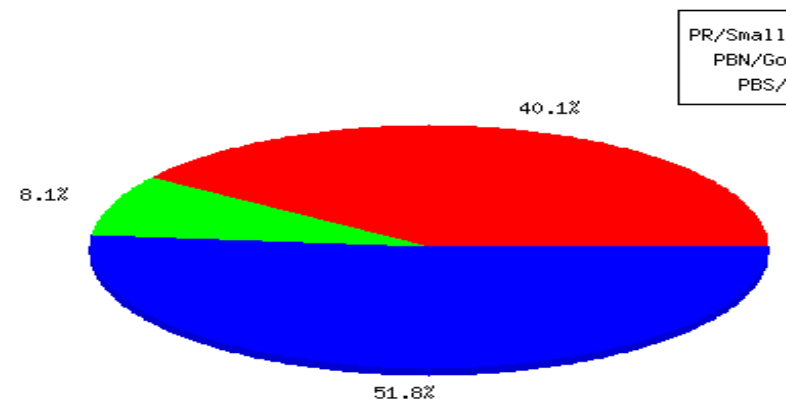

Gambar 1. Luas Areal Perkebunan Kelapa Sawit Seluruh Indonesia menurut Pengusahaan pada tahun 2009

(Sumber : Direktorat Jenderal Perkebunan, Departemen Pertanian) 
Tabel 2. Luas Areal Perkebunan Kelapa Sawit Seluruh Indonesia menurut Pengusahaan

\begin{tabular}{|c|c|c|c|c|}
\hline \multirow{2}{*}{ Tahun } & \multicolumn{4}{|c|}{ Luas Areal (Ha) } \\
\cline { 2 - 5 } & $\begin{array}{c}\text { PR/ } \\
\text { Smallhollders }\end{array}$ & $\begin{array}{c}\text { PBN/ } \\
\text { Government }\end{array}$ & $\begin{array}{c}\text { PBS/ } \\
\text { Private }\end{array}$ & Jumlah \\
\hline 2000 & $1,166,758$ & 588,125 & $2,403,194$ & $\underline{4,158,077}$ \\
\hline 2001 & $1,561,031$ & 609,947 & $2,542,457$ & $\underline{4,713,435}$ \\
\hline 2002 & $1,808,424$ & 631,566 & $2,627,068$ & $\underline{5,067,058}$ \\
\hline 2003 & $1,854,394$ & 662,803 & $2,766,360$ & $\underline{5,283,557}$ \\
\hline 2004 & $2,220,338$ & 605,865 & $2,458,520$ & $\underline{\underline{5,284,723}}$ \\
\hline 2005 & $2,356,895$ & 529,854 & $2,567,068$ & $\underline{\underline{5,453,817}}$ \\
\hline 2006 & $2,549,572$ & 687,428 & $3,357,914$ & $\underline{\underline{6,594,914}}$ \\
\hline 2007 & $2,752,172$ & 606,248 & $3,408,416$ & $\underline{\underline{6,766,836}}$ \\
\hline 2008 & $2,881,898$ & 602,963 & $3,878,986$ & $\underline{7,363,847}$ \\
\hline 2009 & $3,013,973$ & 608,580 & $3,885,470$ & $\underline{7,508,023}$ \\
\hline
\end{tabular}

Sumber : Direktorat Jenderal Perkebunan, Departemen Pertanian,2010

Sejalan dengan perkembangan areal, produksi kelapa sawit juga mengalami peningkatan, dari hanya 7,000,508 ton CPO pada tahun 2000 menjadi $18,640,881$ ton pada tahun 2009, dengan komposisi perkebunan rakyat (PR) memberi andil produksi CPO sebesar $7,247,979$ ton $(38,9 \%)$, perkebunan besar negara $(\mathrm{PBN})$ sebesar $1,961,813$ ton $(10,5 \%)$ dan perkebunan besar swasta(PBS) sebesar 9,431,089 ton $(50,6 \%)$.

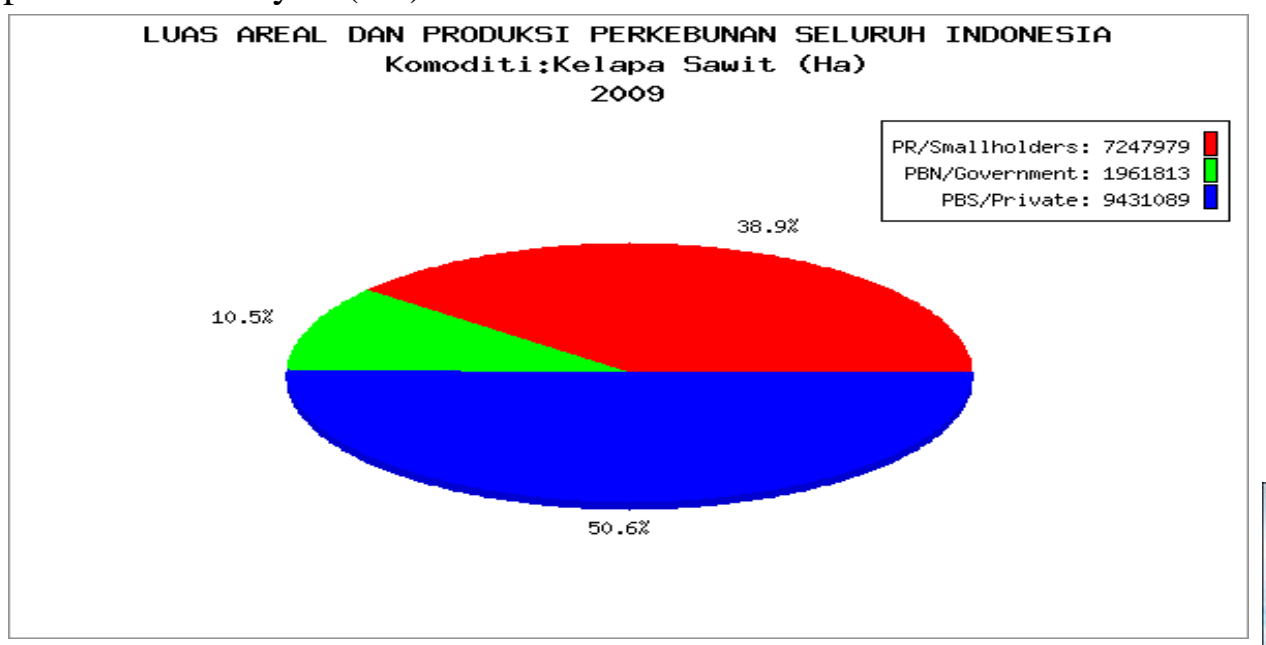

Gambar 2. Produksi Perkebunan Kelapa Sawit Seluruh Indonesia menurut Pengusahaan pada tahun 2009

(Sumber : Direktorat Jenderal Perkebunan, Departemen Pertanian,2009) 


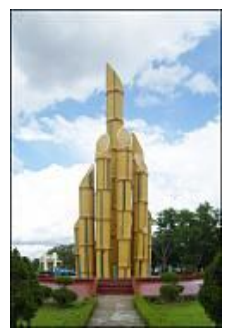

Tabel 3. Produksi Perkebunan Kelapa Sawit Seluruh Indonesia menurut Pengusahaan

Maswadi, Dampak Penerap Pungutan Ekspor Crude Palm

\begin{tabular}{|c|c|c|c|c|}
\hline \multirow{2}{*}{ Tahun } & \multicolumn{4}{|c|}{ Luas Areal (Ha) } \\
\cline { 2 - 5 } & $\begin{array}{c}\text { PR/ } \\
\text { Smallhollders }\end{array}$ & $\begin{array}{c}\text { PBN/ } \\
\text { Government }\end{array}$ & $\begin{array}{c}\text { PBS/ } \\
\text { Private }\end{array}$ & Jumlah \\
\hline 2000 & $1,905,653$ & $1,460,954$ & $3,633,901$ & $\underline{\mathbf{7 , 0 0 0 , 5 0 8}}$ \\
\hline 2001 & $2,798,032$ & $1,519,289$ & $4,079,151$ & $\underline{8,396,472}$ \\
\hline 2002 & $3,426,740$ & $1,607,734$ & $4,587,871$ & $\underline{\underline{9,622,345}}$ \\
\hline 2003 & $3,517,324$ & $1,750,651$ & $5,172,859$ & $\underline{10,440,834}$ \\
\hline 2004 & $3,847,157$ & $1,617,706$ & $5,365,526$ & $\underline{10,830,389}$ \\
\hline 2005 & $4,500,769$ & $1,449,254$ & $5,911,592$ & $\underline{11,861,615}$ \\
\hline 2006 & $5,783,088$ & $2,313,729$ & $9,254,031$ & $\underline{17,350,848}$ \\
\hline 2007 & $6,358,389$ & $2,117,035$ & $9,189,301$ & $\underline{17,664,725}$ \\
\hline 2008 & $6,923,042$ & $1,938,134$ & $8,678,612$ & $\underline{17,539,788}$ \\
\hline 2009 & $7,247,979$ & $1,961,813$ & $9,431,089$ & $\underline{18,640,881}$ \\
\hline
\end{tabular}

Sumber : Direktorat Jenderal Perkebunan, Departemen Pertanian, 2010

Produksi tersebut akan terus meningkat di masa datang, yang berasal dari tanaman belum menghasilkan (TBM) saat ini dan dari pengoptimalan tanaman Sumatera, Kalimantan 11,45\%, 2\% Sulawesi, dan $1 \%$ wilayah lainnya. Produktivitas perkebunan kelapa sawit di Sumatera relatif lebih tinggi dibandingkan dengan di Kalimantan dan Sulawesi.

Perkembangan Ekspor dan Harga Minyak Sawit

Indonesia adalah negara netexporter minyak sawit, tetapi dalam keadaan mendesak Indonesia juga mengimpor minyak sawit. Negara tujuan utama ekspor minyak sawit Indonesia adalah Eropa Barat, India, Pakistan, Cina dan Jepang. Produk yang diekspor adalah minyak olahan tahap awal seperti RBD palm oil, CPO dan beberapa produk oleokimia. Secara umum, ekspor minyak sawit Indonesia 2000-2009 meningkat dengan laju 33,97\%/tahun. menghasilkan (TM) yang telah ada. Perkebunan kelapa sawit juga telah menyebar ke berbagai wilayah Indonesia dengan perbandingan $\quad 85,55 \%$ 
Tabel 4. Volume dan Nilai Ekspor dan Impor Minyak Sawit Indonesia

\begin{tabular}{|c|c|c|c|c|}
\hline \multirow{2}{*}{ Tahun } & \multicolumn{2}{|c|}{ Ekspor } & \multicolumn{2}{c|}{ Impor } \\
\cline { 2 - 5 } & Volume (Ton) & Nilai (000 US\$) & $\begin{array}{c}\text { Volume } \\
\text { (Ton) }\end{array}$ & $\begin{array}{c}\text { Nilai (000 } \\
\text { US\$) }\end{array}$ \\
\hline 2000 & $4,688,852$ & $1,326,398$ & 7,988 & 6,424 \\
\hline 2001 & $5,485,144$ & $1,227,165$ & 5,115 & 2,524 \\
\hline 2002 & $7,072,124$ & $2,348,638$ & 11,861 & 4,745 \\
\hline 2003 & $7,046,303$ & $2,719,304$ & 5,606 & 3,267 \\
\hline 2004 & $9,565,974$ & $3,944,457$ & 7,884 & 5,094 \\
\hline 2005 & $11,418,987$ & $4,344,303$ & 14,067 & 8,366 \\
\hline 2006 & $11,745,954$ & $4,139,286$ & 3,031 & 2,494 \\
\hline 2007 & $13,210,742$ & $8,866,445$ & 4,661 & 7,036 \\
\hline 2008 & $18,141,006$ & $14,110,229$ & 10,994 & 8,953 \\
\hline 2009 & $21,151,127$ & $11,605,431$ & 24,484 & 16,822 \\
\hline
\end{tabular}

Sumber : Direktorat Jenderal Perkebunan, Departemen

Pertanian,2010

Tabel 5. Perkembangan Nilai Ekspor CPO Indonesia, Tahun 2000-2009

\begin{tabular}{|c|c|c|}
\hline Tahun & $\begin{array}{c}\text { Nilai Ekspor (000 } \\
\text { US\$) }\end{array}$ & Pertumbuhan (\%) \\
\hline 2000 & 1.326 .398 & - \\
\hline 2001 & 1.227 .165 & $-7,48$ \\
\hline 2002 & 2.348 .638 & 91,39 \\
\hline 2003 & 2.719 .304 & 15,78 \\
\hline 2004 & 3.944 .457 & 45,05 \\
\hline 2005 & 4.344 .303 & 10,14 \\
\hline 2006 & 4.139 .286 & $-4,72$ \\
\hline 2007 & 8.866 .445 & 114,20 \\
\hline 2008 & 14.110 .229 & 59,14 \\
\hline 2009 & 11.605 .431 & $-17,75$ \\
\hline \multicolumn{2}{|c|}{ Pertumbuhan rata-rata (\%/tahun) } & $\mathbf{3 3 , 9 7}$ \\
\hline
\end{tabular}

Sumber : Departemen Pertanian,2010

Impor minyak sawit umumnya dalam bentuk olein dari Malaysia. Impor ini biasanya terjadi pada waktu harga dunia tinggi dimana terjadi rush export dari Indonesia. Dalam keadaan demikian biasanya pemerintah menggunakan mekanisme pajak ekspor untuk menjamin pasokan dalam negeri yang besarnya pernah mencapai $60 \%$. Dengan pajak ekspor $60 \%$, praktis seluruh pasokan Indonesia diserap oleh pasar domestik, dan tidak ada kelebihan ekspor dari menjual di dalam negeri.

Perkembangan harga minyak sawit (CPO) di pasar 


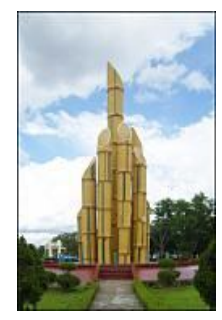

Maswadi, Dampak Penerapan Pungutan Ekspor Crude Palm Oil... domestik dan internasional sejak tahun 1998 sampai dengan 2009 menunjukkan kecenderungan yang menaik. Pergerakan harga minyak sawit di pasar internasional ditransmisikan ke pasar domestik (border price dan whole sale price) melalui mekanisme pasar. Secara umum pergerakan harga minyak sawit domestik searah dengan perkembangan harga minyak sawit di pasar

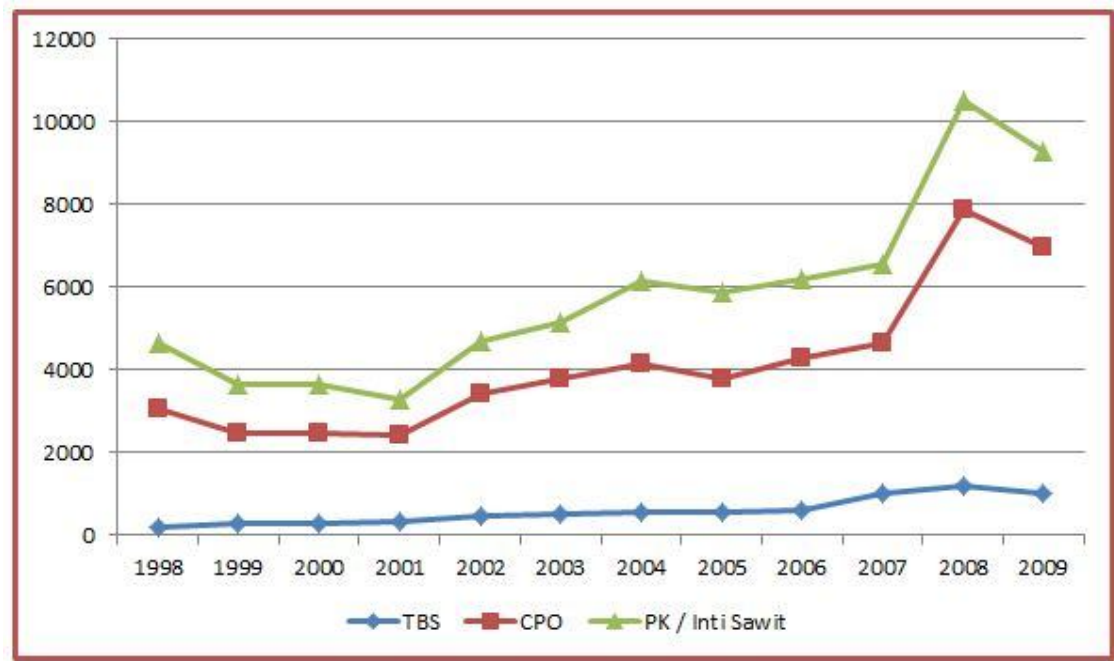

Gambar 3. Perkembangan Harga Minyak Sawit (CPO) (Sumber : BPS,2010) internasional. Selain itu, harga minyak sawit juga mempunyai fluktuasi musiman. Dalam semester 1, harga pada bulan Januari biasanya adalah paling tinggi kemudian turun melandai dalam Februari sampai Mei. Dalam semester 2, penurunan harga yang paling tajam terjadi pada Mei-Juli/ Agustus dan naik sampai dengan bulan Januari. 


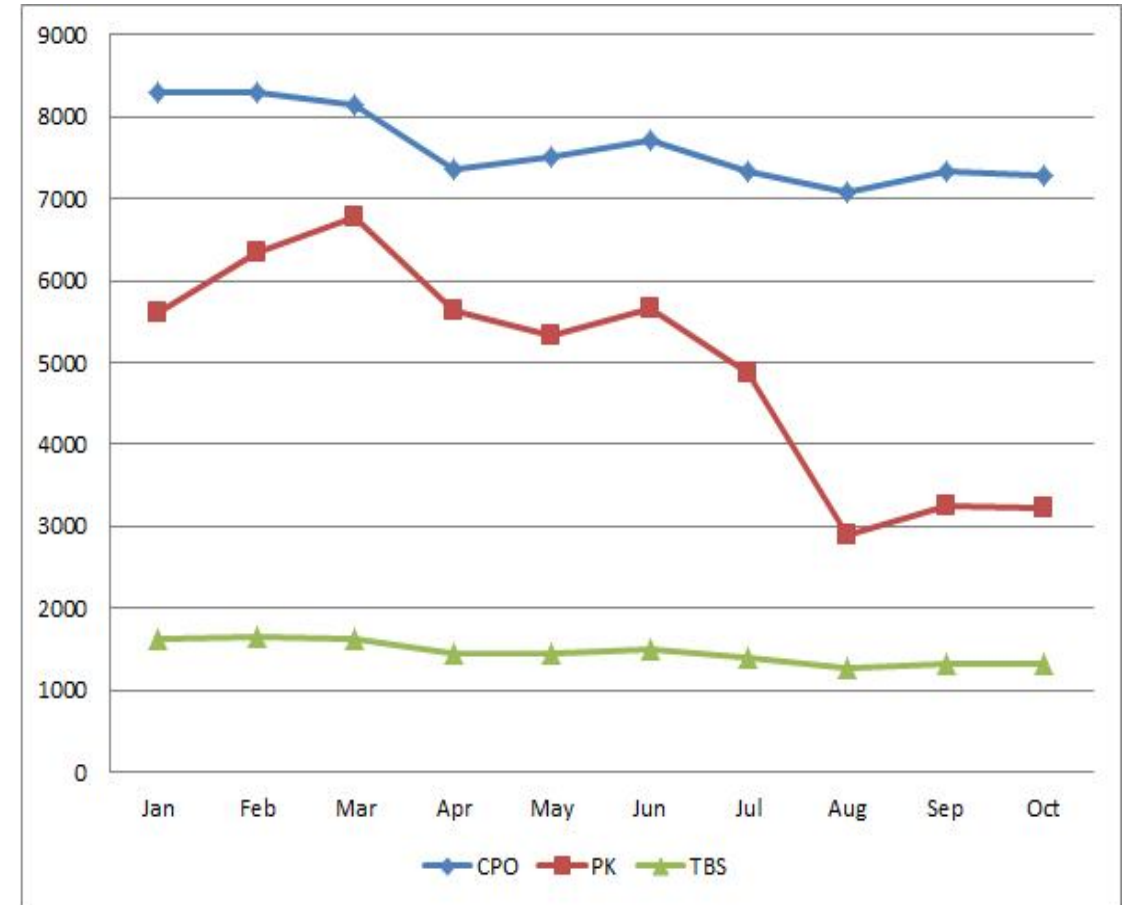

Gambar 4. Pola Harga Minyak Sawit (CPO)(Sumber : BPS,2010)

DAMPAK PENERAPAN PUNGUTAN EKSPOR CPO TERHADAP KINERJA AGRIBISNIS KELAPA SAWIT DAN PENDAPATAN PETANI

Tujuan pengenaan PE untuk barang ekspor tertentu, seperti CPO dan produk turunannya (Pasal 2 ayat 2) adalah untuk (i) menjamin terpenuhinya kebutuhan dalam negeri, (ii) melindungi kelestarian sumber daya alam, (iii) mengantisipasi pengaruh kenaikan harga yang cukup drastis dari barang ekspor tertentu, dan (iv) menjaga stabilitas harga barang tertentu di dalam negeri.

Mencermati tujuan di atas, maka sesungguhnya dimensi manfaat dan keadilan dari PP ini patut dipertanyakan. Dari uraian tentang PE di atas, maka penetapan tujuan PE ini semata-mata hanya memperhatikan kepentingan pembeli domestik dan kepentingan negara (pemerintah) yang dilihat secara parsial. Kepentingan produsen, yaitu perusahaan perkebunan dan petani kelapa sawit, penyedia jasa bisnis dan pemasok input CPO dan produk turunannya terabaikan. Tidak ada pernyataan dalam tujuan yang relevan dengan kepentingan produsen, penyedia jasa bisnis dan pemasok input. Sedangkan kepentingan pelestarian sumber daya alam malahan mendapatkan perhatian khusus yang dinyatakan sebagai tujuan kedua.

Dalam CPO dan produkproduk turunannya, tujuan pertama, ketiga dan keempat merupakan pernyataan yang

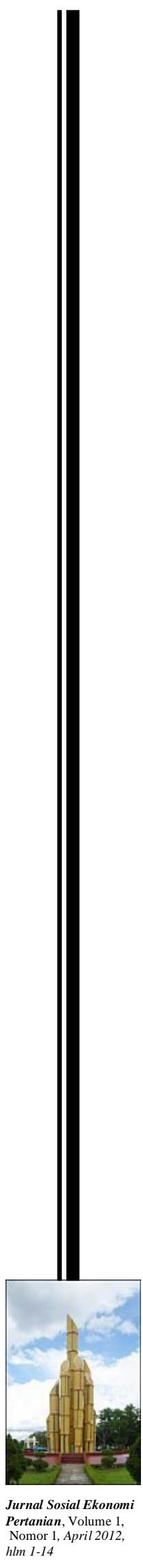




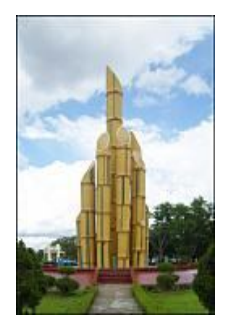

Maswadi, Dampak Penerapan Pungutan Ekspor Crude Palm Oi

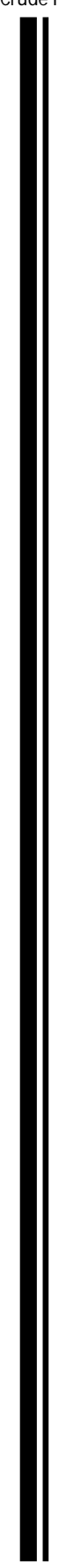

bias ke industri hilir kelapa sawit sehingga industri hilir dapat memperoleh $\mathrm{CPO}$ dan produk turunannya dengan harga rendah (terjangkau) dan stabil. Tujuan kedua melindungi kelestarian sumber daya alam dapat dikatakan terlalu ambigious untuk kasus PE pada produk-produk kelapa sawit. Dalam pemahaman pecinta lingkungan, pertumbuhan yang pesat dari produk-produk kelapa sawit akan mendorong ekspansi pembangunan perkebunan kelapa sawit. Ekspansi ini akan mengeksploitasi sumber daya alam sehingga apabila tidak dikendalikan akan mengganggu kelestarian lingkungan. Protes yang sering muncul berkaitan dengan kelapa sawit dan sumber daya alam adalah karena kelapa sawit ditanam dengan mengkonversi hutan. Untuk hal ini pembangunan perkebunan kelapa sawit diklaim sebagai pembangunan yang tidak memperhatikan kelestarian lingkungan. Dalam konteks pencapaian tujuan, lantas bagaimana PE dapat melindungi kelestarian sumber daya alam?. Pencantuman tujuan untuk melindungi kelestarian sumber daya alam sekaligus dapat diartikan sebagai pembenaran atas adanya masalah kelestarian sumber daya alam dalam kaitannya dengan pembangunan perkebunan kelapa sawit.

Masih dalam konteks tujuan, pertanyaan lain adalah bagaimana PE mengakomodasi kepentingan produsen yaitu perusahaan perkebunan dan petani kelapa sawit, penyedia jasa bisnis dan pemasok input CPO dan produk turunannya? Produsen menanggung beban PE dan tidak ada pernyataan tujuan yang melindungi kepentingan produsen. Sebagai suatu kebijakan publik selayaknya memperhatikan dampaknya terhadap seluruh stakeholders.

Dengan memahami uraian di atas, maka dapat dinyatakan bahwa tujuan pengenaan PE pada CPO dan produk-produk turunannya sesuai PP No.35 Tahun 2005 belum menerapkan dengan baik nilai manfaat dan rasa keadilan bagi stakeholders terutama produsen CPO termasuk petani dan pelaku jasa bisnis berkaitan dengan perdagangan CPO dan produk-produk turunannya. Tujuan untuk melindungi kelestarian sumber daya alam juga masih belum jelas kepastian hukumnya tentang bagaimana mencapainya.

Saat ini pemerintah telah menetapkan PE atas CPO sebesar 3 persen dari HPE CPO. Namun besaran HPE atas CPO belum ditetapkan. Ada dua kemungkinan yang akan terjadi berkaitan dengan $\mathrm{PE}$ CPO yaitu: (1) pemerintah menetapkan besaran HPE sebesar $1 / 3$ dari harga CPO dunia yang berlaku yang berarti setara dengan PE sebesar 1 persen dari harga CPO dunia yang berlaku; (2) pemerintah merevisi besaran PE dari 3 persen menjadi 1 
persen, tetapi HPE ditetapkan sebesar harga CPO dunia yang berlaku.

Produk Domestik Bruto

Dampak kontraksi dan ekspansi dari penerapan PE tersebut secara umum akan tercermin dari PDB. Apabila PDB meningkat mengidentifikasikan bahwa PE tersebut berdampak positif terhadap perkembangan ekonomi nasional, tetapi sebaliknya jika PDB menurun. Penerapan PE akan menyebakan penurunan PDB disemua skenario. Dampak penerapan PE 3 persen terhadap penurunan PDB lebih besar dibanding PE 1 persen. Ini mengindikasikan bahwa peningkatan PE ternyata tidak mampu mengakselerasi kegiatan industri hilir dalam negeri yang menciptakan nilai tambah lebih besar untuk mengkompensasi kehilangan nilai tambah akibat konstraksi dari penerapan PE pada kegiatan agribisnis kelapa sawit. Oleh karena itu, disarankan agar pemerintah tidak menerapkan PE terlalu tinggi dibanding yang berlaku sekarang.

\section{Agribisnis Kelapa Sawit}

Pengenaan PE berdampak pada penurunan luas tanaman menghasilkan yang selanjutnya berdampak pada penurunan kesempatan kerja, dan penurunan produksi CPO. Tambahan penerimaan pemerintah dari PE ternyata tidak mampu menaikkan pertumbuhan PDB justru sebaliknya, sehingga penerapan PE kurang menguntungkan dilihat dari aspek kinerja ekonomi makro. Apabila pemerintah tetap menerapkan kebijakan PE CPO maka disarakan untuk menerapkan PE sebesar 3 persen dengan HPE $1 / 3$ dari harga CPO dunia yang berlaku. Pendapatan Petani

Kenaikan PE menjadi 3\% menyebabkan harga TBS semakin rendah. Penurunan harga TBS menyebabkan keuntungan petani menjadi menurun. Jika diasumsikan 1 KK petani kelapa sawit memiliki lahan rata-rata 2 ha dengan produktivitas 15 ton TBS/ha/tahun maka keuntungan per KK menurun dari sekitar Rp. 5,8 juta menjadi hanya Rp. 2,6 juta. Karena beban PE dapat dialihkan ke petani, maka beban pungutan ekspor yang besar itu sebagian diantaranya akan dibebankan pengusaha kepada petani. Jadi, jika pemerintah menaikkan PE menjadi 3\%, maka pendapatan petani akan menurun.

\section{SIMPULAN}

Kesimpulan yang dapat dibuat berdasarkan pembahasan tentang dampak penerapan pungutan ekspor CPO terhadap kinerja agribisnis kelapa sawit dan pendapatan petani adalah:

1. Penerapan PE akan menyebakan penurunan PDB disemua skenario kegiatan agribisnis kelapa sawit. Dampak penerapan PE 3 persen terhadap penurunan PDB lebih besar dibanding PE 1 persen. Ini mengindikasikan bahwa

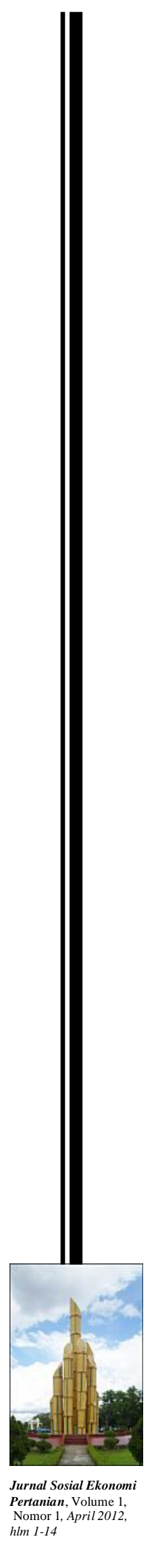




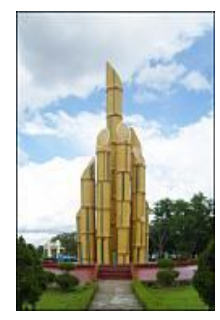

Maswadi, Dampak Penerapan Pungutan Ekspor Crude Palm Oil... peningkatan PE ternyata tidak mampu mengakselerasi kegiatan industri hilir dalam negeri yang menciptakan nilai tambah lebih besar untuk mengkompensasi

kehilangan nilai tambah akibat konstraksi dari penerapan PE pada kegiatan agribisnis kelapa sawit.

2. Pengenaan PE juga berdampak pada penurunan luas tanaman yang selanjutnya berdampak pada penurunan kesempatan kerja, dan penurunan produksi CPO.

3. Kenaikan PE menjadi $3 \%$ menyebabkan harga TBS semakin rendah. Penurunan harga TBS menyebabkan keuntungan petani akan menurun.

\section{DAFTAR PUSTAKA}

Abd dan Muhammad Nur. 2002. Analisis Ekspor Kelapa Sawit Indonesia. Jurnal Ekonomi dan Bisnis. Vol. 1 No. 3, 2002. Fakultas Ekonomi Universitas Syiah Kuala. Arwansyah, 2002. Pengaruh

Nilai Tukar Rupiah Terhadap Ekspor dan Impor Indonesia. Jurnal Ekonomi dan Pembangunan, Vol VI, No. 3, September 2002, Hal. 35-47. Bappeda.

Budiasa, I Wayan. 2010. Studi

Kelayakan Proyek Perkebunan Kelapa Sawit PT. Henrison Inti Persada, Papua. Jurnal
Agribisnis. Universitas Udayana, Denpasar-Bali. Badan Pusat Statistik. 2010. Produksi Perkebunan Besar menurut Jenis Tanaman, Indonesia. Jakarta.

Direktorat Jenderal Perkebunan. 2010. Luas Areal dan Produksi Kelapa Sawit menurut Pengusahaan. Jakarta. Diakses pada tanggal 4 Desember 2011 dari: http://ditjenbun.deptan.g o.id/cigraph/index.php/vi ewstat/komoditiutama/8Kelapa\%20Sawit

Direktorat Jenderal Perkebunan. 2010. Volume dan Nilai Ekspor, Impor Kelapa Sawit Indonesia. Jakarta. Diakses pada tanggal 4 Desember 2011 dari:

http://ditjenbun.deptan.g o.id/cigraph/index.php/vi ewstat/exportimport/16kelapa\%20sawit

Departemen Pertanian. 2007.

Prospek dan Arah Pengembangan

Agribisnis Kelapa

Sawit.Departemen

Pertanian, Jakarta.

Departemen Pertanian. 2000.

Kajian Pasar dan Peluang Investasi Kelapa Sawit. Departemen Pertanian, Jakarta.

Departemen Pertanian. 2010. Statistik Perkebunan Indonesia. Jakarta

Dinas Perkebunan Kalimantan Barat. 2011. Statistik 
Komoditi Kelapa Sawit. Pontianak

Jhingan, M.L. 2002. Ekonomi

Pembangunan dan

Perencanaan. Edisi

Keenambelas,

Cet.Kesembilan,

Rajawali Pers, Jakarta.

Lihan, Irham dan Yogi. 2003.

Analisis Perkembangan

Ekspor

dan

Pengaruhnya Terhadap

Pertumbuhan Ekonomi

Indonesia. Jurnal

Ekonomi dan Bisnis No. 1,

Jilid 8, Tahun2003.

Fakultas Ekonomi

Universitas Lampung,

Lampung.

Munadi, Ernawati. 2007.

Penurunan Pajak Ekspor

dan Dampaknya

Terhadap Ekspor

MinyakKelapa Sawit

Indonesia. Jurnal

Informatika Pertanian, Vol.

16 No. 2, 2007.Fakultas

Ekonomi Universitas
Wijaya Kusuma.

Saragih,Bungaran.2000.

Agribisnis Sebagai

Landasan

Pembangunan Ekonomi

IndonesiaDalam Era

Millenium Baru. Jurnal

Studi Pembangunan,

Kemasyarakatan \&

Lingkungan, Vol 2, No.1.

Sawitriyadi dan Effendi, R. 2009. Faktor-Faktor Penentu Ekspor

Minyak Kelapa Sawit

(Crude Palm Oil)

Indonesia. Jurnal

Ekonomi dan BisnisVol.

8, No. 3. Fakultas

Ekonomi Universitas

Syiah Kuala. Diakses pada tanggal 4 Desember 2011 dari:

http://jurnal.fe-

unsyiah.org/wp-

content/uploads/2011/11/

v8.3.7.-Rustam-

Effendi.pdf 